\title{
THE ROLE OF MOLECULAR GENETICS IN THE PRENATAL DIAGNOSIS OF RETINAL DYSTROPHIES
}

\author{
K. EVANS, C. Y. GREGORY, A. FRYER, J. WHITTAKER, J. DUVALL-YOUNG, \\ A. C. BIRD, M. R. JAY and S. S. BHATTACHARYA \\ London
}

\begin{abstract}
SUMMARY
Inherited retinal dystrophies are important causes of incurable blindness in developed countries. Advances in molecular genetics promise significant improvements in their management. Immediate benefits of present knowledge are presymptomatic and prenatal diagnosis in selected cases. To study the predictive power of these techniques a simulated genetic risk estimation was undertaken in a cone-rod retinal dystrophy pedigree known to be linked to chromosome 19. Using data on five fully informative, flanking DNA markers, phenotype was correctly assigned with only a $2 \%$ probability of error. If the two most closely linked markers were found to be uninformative, this error probability remained unchanged. Using genetic risk calculations and direct mutation detection many retinal dystrophies could now be identified by prenatal diagnosis.
\end{abstract}

It has been estimated that there are 31 million people blind world-wide, 1.5 million of whom are children. ${ }^{1}$ In Great Britain there are 959000 adults considered legally blind or partially sighted and between 10000 and 25000 children under 16 years of age with a severe visual disability. In two Royal National Institute for the Blind (RNIB) surveys of blindness in the United Kingdom ${ }^{2,3}$ disability due to choroidoretinal dystrophy was not individually categorised; however, $24 \%$ of adults gave genetic causes for their blindness such as 'heredity' and 'retinitis pigmentosa'. The parents of $23 \%$ of British children blind or partially sighted reported 'heredity' or 'parents incompatible' as a cause for 'their visual deficit. A review of a number of studies in Europe, Australia and the United States ${ }^{4}$ has suggested that as much as $50 \%$ of blindness in children in the developed world is genetically determined.

From: Department of Clinical Ophthalmology, Moorfields Eye Hospital, and Department of Molecular Genetics, Institute of Ophthalmology, London, UK.

Correspondence to: Kevin Evans, Department of Clinical Ophthalmology, Moorfields Eye Hospital, City Road, London EC1V 2PD, UK.
There are few published details on the incidence or prevalence of choroidoretinal dystrophies. Retinitis pigmentosa is thought to affect approximately 1.5 million people world-wide. Prevalence figures from developed countries including Great Britain consistently report figures of approximately 1:5000 births. $^{5-9}$ There are approximately 25000 retinitis pigmentosa sufferers in Great Britain, with a total of 100000 sufferers in Europe and a similar number in the United States. ${ }^{10}$ Adding these statistics to the unknown number with other retinal dystrophies suggests that as a group they contribute significantly to the prevalence of blindness in these and other developed countries. As yet there are no cures for these conditions and management is often limited to helping patients to cope with their handicaps.

Rapid advances in molecular genetics promise to improve this situation. A number of causative genes have now either been localised in the genome or specific mutations identified. These developments will lead to a better understanding of the pathophysiology of these conditions and prospects for new therapeutic strategies including gene therapy. From a more immediate, practical viewpoint, presymptomatic genetic diagnosis of certain retinal conditions from peripheral blood samples is now possible.

Typical of the progress that is being made is recent work on the molecular genetics of cone-rod retinal dystrophy (CRD), ${ }^{11}$ an uncommon but severe cause of early-onset blindness. Linkage analysis in this and other retinal dystrophies has raised the possibility of accurate, early diagnosis even in those with nonspecific clinical signs. In one large autosomal dominant CRD pedigree the disease locus has been localised to a 5 centimorgan region on chromosome 19 q. ${ }^{12}$ Here we present the results of a study to develop this work sufficiently to allow for accurate prenatal diagnosis of the condition using highly polymorphic DNA markers closely linked and flanking the disease locus. 


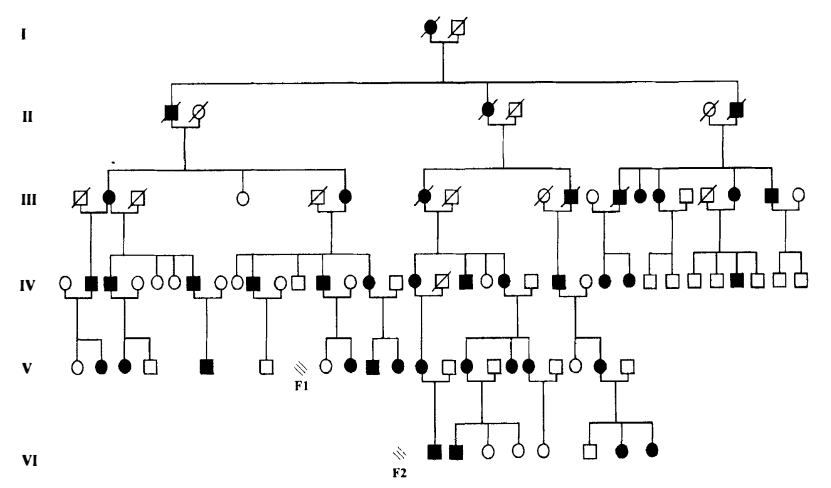

Fig. 1 Autosomal dominant cone-rod retinal dystrophy (CRD) pedigree. Hypothetical subjects F1 and F2 are indicated.

\section{METHODS}

Patients

DNA samples from 71 members of the family originally linked to the $19 \mathrm{q}$ locus were used. The pedigree comprises six generations with 56 potentially informative meioses (Fig. 1). The phenotype expressed in the family has been characterised by clinical, electrophysiological and psychophysical investigations as an early-onset, severe dystrophy with best recorded visual acuities of $6 / 60$ at 6 years of age declining to bare or no perception of light by the sixth decade of life. ${ }^{13}$ Local ethics committee approval and informed patient consent were obtained before the study was undertaken.

\section{Laboratory Techniques}

Four dinucleotide repeat microsatellite DNA markers - D19S211, D19S219, D19S246 and $K L K^{14}$ known to flank the 19qCRD locus closely were used to genotype individuals by polymerase chain reaction (PCR) amplification of $100 \mathrm{ng}$ DNA samples using standard protocols. ${ }^{15}$ A fifth marker, $H R C$, known to map between D19S219 and D19S246 but not previously linked to the CRD locus, was also used. This identifies an intragenic trinucleotide repeat polymorphism in exon 1 (starting nucleotide position 742) of a gene coding for a histidine-rich calcium binding protein. ${ }^{16}$ One primer of each marker was end-labelled with $\left[\gamma^{32} \mathrm{P}\right]$ ATP. Radioactive PCR products were fractionated by denaturing polyacryl- amide gel electrophoresis, dried and autoradiographed.

\section{Linkage Analysis}

The LINKSYS information management package version $3.1^{17}$ was used to prepare data for linkage analysis. Two-point lod scores were obtained using the MLINK program of the LINKAGE software package version 5.2. ${ }^{18}$ Allele frequencies were calculated using genotype data from 15 unrelated individuals ${ }^{19}$ and the genetic distances between markers were as published.

Genetic risk is defined as the probability (conditional on observations in relatives) that an individual may develop a genetically inherited condition. In prenatal diagnosis, fetal DNA can be obtained by amniocentesis or trans-abdominal chorionic villus sampling $^{20}$ and genotyped in the usual way. For the calculation of disease risk, the subprogram MLINK was again used. To assess the predictive power of the analysis in this family two separate simulations were undertaken. Subjects V-11 and V-12 were allocated the hypothetical offspring 'F1'. Subjects IV-13 and IV-14 were allocated 'F2' (Fig. 1). Marker alleles were designated in a way that would be associated with an affected status. Both hypothetical offspring were allocated the marker allele associated with disease in the pedigree and the most informative spouse allele. Linkage pedigree files were then modified to assign the hypothetical subject as proband and the subprogram PREPLINK used to modify datafiles for risk calculations. ${ }^{21}$ To give a $95 \%$ confidence interval to account for possible error in calculated distances between markers and disease, risk calculation errors were calculated at the $95 \% \theta$ interval where $\theta$ represents recombination fraction.

\section{RESULTS}

Table I presents the results of the genetic risk simulations for subjects F1 and F2. All markers were informative for subject $\mathrm{F} 1$ giving risk error estimates of $18 \%$ and $12 \%$ respectively with informative flanking markers D19S219 and HRC. The combined risk error was therefore $2 \%$. However, both were uninformative for subject F2 due to parental genotype homozygosity for each marker.

Table I. Linkage date for chromosome 19q markers and simulated risk estimations for subjects F1 and F2

\begin{tabular}{|c|c|c|c|c|c|c|c|c|c|}
\hline \multirow[b]{2}{*}{ Marker } & \multirow[b]{2}{*}{$\mathrm{Z}_{\max }$} & \multirow[b]{2}{*}{$\theta$} & \multirow[b]{2}{*}{$\begin{array}{l}95 \% \\
\text { CI } \theta\end{array}$} & \multicolumn{3}{|c|}{ Subject F1 } & \multicolumn{3}{|c|}{ Subject F2 } \\
\hline & & & & $\begin{array}{l}\text { Affected } \\
\text { risk (\%) }\end{array}$ & $\begin{array}{l}95 \% \mathrm{CI} \\
\text { risk (\%) }\end{array}$ & $\begin{array}{c}\text { Error } \\
\text { risk (\%) }\end{array}$ & $\begin{array}{l}\text { Affected } \\
\text { risk (\%) }\end{array}$ & $\begin{array}{l}95 \% \mathrm{CI} \\
\text { risk }(\%)\end{array}$ & $\begin{array}{c}\text { Error } \\
\text { risk }(\%)\end{array}$ \\
\hline D19S211 & 9.0 & 0.06 & 0.20 & 94 & 80 & 20 & 94 & 80 & 20 \\
\hline D19S219 & 7.9 & 0.03 & 0.18 & 97 & 82 & 18 & 50 & 50 & 50 \\
\hline$H R C$ & 6.9 & 0.01 & 0.12 & 99 & 88 & 12 & 50 & 50 & 50 \\
\hline D19S246 & 13.0 & 0.02 & 0.10 & 97 & 90 & 10 & 98 & 89 & 11 \\
\hline$K L K$ & 13.0 & 0.06 & 0.10 & 94 & 90 & 10 & 94 & 90 & 10 \\
\hline
\end{tabular}

$\mathbf{Z}_{\max }$, maximum lod score; $\theta$, theta value at $\mathbf{Z}_{\max } ; 95 \%$ CI risk, lowest probability of affected status at $95 \%$ CI $\theta$ (2-lod confidence interval); arror risk, the risk of incorrect disease status allocation at the 2-lod confidence interval. 
Informative flanking markers closest to the disease locus were therefore D19S211 and D19S246, which gave independent risk error estimates of $20 \%$ and $11 \%$. The combined risk error was $2.2 \%$.

The bank of five DNA markers correctly assigned disease status as affected in each case with an approximate $2 \%$ probability of error (at the $95 \%$ confidence interval) even though, in the second simulation, markers known to be most closely linked were uninformative. Therefore, in a real situation even if certain markers prove to be uninformative, others in the bank should allow for confident risk estimations. It was noted during laboratory work that PCR amplification with marker $H R C$ required repeat procedures to enhance conditions sufficiently to interpret genotypes. In a diagnostic service strategy another, more robust marker would be used to optimise the success rate of the protocol.

\section{DISCUSSION}

With a number of flanking markers, the risk of a fetus carrying the CRD disease gene can be calculated with a high degree of accuracy if, as in this family, the disease locus is known and haplotype data from other family members are available. If some markers prove uninformative, the density of others in the $19 q$ region allows for other informative systems to be used. The error estimate calculated takes account of the possibility that a double crossover has occurred within the region bounded by the markers. This was 3.7 centimorgans $(\mathrm{cM})$ in the first simulation and 8 $\mathrm{cM}$ in the second. These figures do not take into account procedural error due, for example, to contamination of fetal DNA with blood from the mother. Stringent sampling and laboratory techniques would be required to reduce such error and an approximately $1 \%$ error rate would also be added to the final error estimate.

Over the last decade a number of retinal dystrophies have been linked to specific genomic regions. Linkage data for autosomal dominant conditions such as retinitis pigmentosa, ${ }^{22-26}$ Best's disease ${ }^{27}$ and cystoid macular dystrophy, ${ }^{28}$ autosomal recessive conditions such as Usher's syndrome, ${ }^{29-32}$ Stargardt's disease ${ }^{33}$ and Bardet-Biedl syndrome, ${ }^{34}$ and $\mathrm{X}$-linked conditions such as incontinentia pigmenti ${ }^{35}$ and $X$-linked retinitis pigmentosa $a^{36,37}$ are now available to allow for these conditions to be considered for presymptomatic testing. In addition mutations in the genes encoding rhodopsin, ${ }^{38}$ peripherin/rds, ${ }^{39-43}$ the beta subunit of phosphodiesterase $^{44}$ and the choroideraemia associated gene ${ }^{45}$ now allow for accurate, presymptomatic, direct mutation detection in families where this has been shown to segregate with disease. A prerequisite for such a service, however, is that molecular genetic analysis has been undertaken before conception. The identification of a specific mutation or linkage to a genomic locus requires analysis of DNA from a number of family members. If the disease segregating in the family is not linked to a known locus, establishing linkage could take many months. In addition the possibility of variable expression or incomplete penetrance of phenotype in particular families, especially of autosomal dominant conditions, needs to be considered since in such cases disease-gene carrier status may result in very mild or no phenotypic expression.

Prenatal diagnosis for retinal dystrophies has already been used in selected families with X-linked retinitis pigmentosa, choroideraemia ${ }^{46}$ and Norrie's disease, although in this last case multisystem abnormalities, especially of the central nervous system, were probably the main impetus rather than ophthalmic considerations. ${ }^{47}$ No study to assess the requirements of such a service has been carried out in Great Britain or the United States although such studies have been undertaken in mainland Europe. Members of the German Retinitis Pigmentosa Society underwent a questionnaire survey on attitudes to prenatal diagnosis for retinitis pigmentosa. ${ }^{10}$ Of the 414 respondents, $64 \%$ thought that prenatal diagnosis was appropriate. A similar study in Sweden found that $60 \%$ had a positive attitude towards prenatal diagnosis. ${ }^{48}$ Both studies found that although most people would take up an offer of prenatal diagnosis this did not imply that they would then accept termination of an affected pregnancy. In the former study, over $32 \%$ responded that they would disagree with termination if the child were destined to be blind soon after birth and $61 \%$ would decline if the onset of blindness was to be in adulthood. The latter study also found that although prenatal diagnosis would be used, over $30 \%$ would not use this information to decide on termination. Similar attitudes are now being found in studies in other conditions such as cystic fibrosis, ${ }^{49}$ Marfan's syndrome $^{50}$ and sickle cell disease. ${ }^{51}$

Therefore, although a high proportion of people with retinal dystrophies appear to approve of prenatal diagnosis, and evidence suggests that they would use it, not all would then undergo selective termination. Relief from the anxiety of the unknown and better preparation of both parents and health care workers for the arrival of a handicapped child have been cited as possible justifications by parents for these tests. ${ }^{50}$ It is well established that the respondents to questionnaire studies may not in the fullness of time carry out their stated intentions. The responses may change dramatically when these choices are no longer theoretical. However, a number of studies have found that a majority retain and act on their views as stated in such 
questionnaires, especially if they consider the child's predicted handicap to be severe. ${ }^{49}$

Such a service may be justified as a patient requirement in the management of retinal dystrophies. It is unlikely, though, that prenatal diagnosis and selective termination will ever become widespread in ophthalmic practice since other, more acceptable techniques such as in vitro fertilisation with pre-implantation selection, and somatic cell gene therapy, may soon be realities.

Key words: Prenatal diagnosis, Retinal dystrophies.

\section{REFERENCES}

1. Foster A, Johnson G. Blindness in the developing world. Br J Ophthalmol 1993;77:398-9.

2. Bruce I, McKennell A, Walker E. Blindness and partially sighted adults in Britain: the RNIB survey. London: HMSO Publications Centre, 1991.

3. Walker E, Tobin M, McKennell A. Blind and partially sighted children in Britain: the RNIB survey. London: HMSO Publications Centre, 1992.

4. Elston J. Epidemiology of visual handicap in childhood. In Taylor D, editor. Pediatric ophthalmology. Oxford: Blackwell Scientific, 1992:3-6.

5. Bunker $\mathrm{CH}$, Berson EL. Prevalence of retinitis pigmentosa in Maine. Am J Ophthalmol 1984;97: 357-65.

6. Grondahl J. Estimation of prognosis and prevalence of retinitis pigmentosa and Usher syndrome in Norway. Clin Genet 1987;31:25-64.

7. Rosner M, Hefetz L, Abraham FA. The prevalence of retinitis pigmentosa and congenital stationary night blindness in Israel. Am J Ophthalmol 1993;116:373-4.

8. Bundey S, Crews SJ. A study of retinitis pigmentosa in the city of Birmingham. I. Prevalence. J Med Genet 1984;21:417-20.

9. Bundey S, Crews SJ. A study of retinitis pigmentosa in the city of Birmingham. II. Clinical and genetic heterogeneity. J Med Genet 1984;21:421-8.

10. Pawlowitzki IH, Ruther K, Brunsmann F, Von Gizycki R. Acceptability of prenatal diagnosis for retinitis pigmentosa. Lancet 1986;2:1394-5.

11. Evans K, Fryer A, Inglehearn C, Duvall-Young J, Whittaker JL, Gregory CY, et al. Genetic linkage of cone-rod retinal dystrophy to chromosome $19 \mathrm{q}$ and evidence for segregation distortion. Nature Genet 1994;6:210-3.

12. Gregory CY, Evans K, Whittaker JL, Fryer A, Weissenbach J, Bhattacharya SS. Refinement of the cone-rod retinal dystrophy locus on chromosome 19q. Am J Hum Genet 1994;55:1061-3.

13. Evans K, Duvall-Young J, Fitzke FW, Arden GB, Bhattacharya SS, Bird AC. Chromosome 19 cone-rod retinal dystrophy: ocular phenotype. Arch Ophthalmol 1995 (in press).

14 Weber JL, Wang Z, Hansen K, Stephenson M, Kappel $\mathrm{C}$, Salzman S, et al. Evidence for human meiotic recombination interference obtained through construction of a short tandem repeat-polymorphism linkage map of chromosome 19. Am J Hum Genet 1993;53:1079-95.

15. Saiki RK, Gelfand DH, Stoffel S, Scharf SJ, Higuchi R, Horn GT, et al. Primer-directed enzymic amplification of DNA with a thermostable DNA polymerase. Science 1988;239:487-91.

16. Hofmann SL, Topham P, Hsieh C, Francke U. cDNA and genomic cloning of HRC, a human sarcoplasmic reticulum protein, and localisation of the gene to human chromosome 19 and mouse chromosome 7. Genomics 1991;9:656-69.

17. Attwood J, Bryant S. A computer program to make analysis with LIPED and LINKAGE easier to perform and less prone to input error. Ann Hum Genet 1988;52:259.

18. Lathrop GM, Lalouel JM, Julier C, Ott J. Strategies for multipoint linkage analysis in humans. Proc Natl Acad Sci USA 1984;81:3443-6.

19. Ott J. Strategies for characterising highly polymorphic markers in human genome mapping. Am J Hum Genet 1992;51:283-90.

20. Lilford RJ, Irving HC, Linton G, Mason MK. Transabdominal chorion villous biopsy: 100 consecutive cases. Lancet 1987;1:1415-6.

21. Ott J. Analysis of human genetic linkage. Baltimore: Johns Hopkins University Press, 1985.

22. Farrar GJ, Findlay JB, Kumar Singh R, Kenna P, Humphries MM, Sharpe E, Humphries P. Autosomal dominant retinitis pigmentosa: a novel mutation in the rhodopsin gene in the original $3 q$ linked family. Hum Mol Genet 1992:1:769-71.

23. Jordan SA, Farrar GJ, Kumar Singh R, Kenna P, Humphries MM, Allamand V, et al. Autosomal dominant retinitis pigmentosa (adRP; RP6): cosegregation of RP 6 and the peripherin-RDS locus in a lateonset family of Irish origin. Am J Hum Genet 1992;50:634-9.

24. Jordan SA, Farrar GJ, Kenna P, Humphries MM, Sheils DM, Kumar Singh R, et al. Localisation of an autosomal dominant retinitis pigmentosa gene to chromosome 7q. Nature Genet 1993;4:54-8.

25. Blanton SH, Heckenlively JR, Cottingham AW, Friedman J, Sadler LA, Wagner M, et al. Linkage mapping of autosomal dominant retinitis pigmentosa (RP1) to the pericentric region of human chromosome 8 . Genomics 1991;11:857-69.

26. Al Maghtheh M, Inglehearn CF, Keen TJ, Evans $\mathrm{K}$, Moore AT, Jay M, et al. Identification of a sixth locus for autosomal dominant retinitis pigmentosa on chromosome 19. Hum Mol Genet 1994;3:351-4.

27. Nichols BE, Bascom R, Litt M, McInnes R, Sheffield VC, Stone EM. Refining the locus for Best vitelliform macular dystrophy and mutation analysis of the candidate gene ROM1. Am J Hum Genet 1994;54:95-103.

28. Kremer H, Pinckers A, van den Helm B, Deutman AF, Ropers H, Mariman ECM. Localisation of the gene for dominant cystoid macular dystrophy on chromosome 7p. Hum Mol Genet 1994;3:299-302.

29. Kimberling WJ, Weston MD, Moller C, Davenport SLH, Shugart YY, Priluck IA, et al. Localisation of Usher syndrome type II to chromosome 1q. Genomics 1990;7:245-9.

30. Smith RJ, Lee EC, Kimberling WJ, Daiger SP, Pelias $\mathrm{MZ}$, Keats BJ, et al. Localisation of two genes for Usher syndrome type I to chromosome 11. Genomics 1992;14:995-1002.

31. Kimberling WJ, Moller CG, Davenport S, Priluck IA, Beighton PH, Greenberg J, et al. Linkage of Usher syndrome type I gene (USH1B) to the long arm of chromosome 11. Genomics 1992;14:988-94.

32. Kaplan J, Gerber S, Bonneau D, Rozet JM, Delrieu O, Briard ML, et al. A gene for Usher syndrome type I (USH1A) maps to chromosome $14 \mathrm{q}$. Genomics 1992;14:979-87.

33. Kaplan J, Gerber S, Larget-Piet D, Rozet J, Dollfus H, 
Dufier J, et al. A gene for Stargardt's disease (fundus flavimaculatus) maps to the short arm of chromosome 1. Nature Genet 1993:5:308-11.

34. Kwitek-Black AE, Carmi R, Duyk GM, Buetow KH, Elbedour K, Parvari R, et al. Linkage of Bardet-Biedl syndrome to chromosome $16 \mathrm{q}$ and evidence for nonallelic genetic heterogeneity. Nature Genet 1993;5: 392-6.

35. Sefiani A, Heuertz S, Turleau C, Thibaud D, De Grouchy J, Hors Cayla MC. Incontinentia pigmenti: $\mathrm{Xp}$ is not the same in a case of $\mathrm{r}(\mathrm{X})$ and in $\mathrm{X}$ /autosome translocations. Ann Genet 1989;32:149-51.

36. Bhattacharya SS, Wright AF, Clayton JF, et al. Close genetic linkage between $\mathrm{X}$-linked retinitis pigmentosa and a restriction fragment length polymorphism identified by recombinant DNA probe L1.28. Nature 1984;309:253-5.

37. Musarella MA, Burghes A, Anson-Cartwright L, Mahtani MM, Argonza R, Tsui L-C, Worton R. Localisation of the gene for $\mathrm{X}$-linked recessive type of retinitis pigmentosa (XLRP) to Xp21 by linkage analysis. Am J Hum Genet 1988;43:484-94.

38. Al Maghtheh M, Gregory CY, Inglehearn CF, Hardcastle A, Bhattacharya SS. Rhodopsin mutations in autosomal dominant retinitis pigmentosa. Hum Mutat 1993;2:249-55.

39. Farrar GJ, Kenna P, Jordan SA, Kumar Singh R, Humphries MM, Sharp EM, et al. A three-base-pair deletion in the peripherin-RDS gene in one form of retinitis pigmentosa. Nature 1991;354:478-80.

40. Keen TJ, Inglehearn CF, Kim R, Bird AC, Bhattacharya S. Retinal pattern dystrophy associated with a 4 bp insertion at codon 140 in the RDS-peripherin gene. Hum Mol Genet 1994;3:367-8.

41. Kajiwara K, Hahn LB, Mukai S, Berson EL, Dryja TP. Mutations in the human RDS gene in patients with autosomal dominant retinitis pigmentosa. Invest Ophthalmol Vis Sci 1992;33:1396.

42. Farrar GJ, Kenna P, Jordan SA, Kumar Singh R, Humphries MM, Sharp MM, et al. Autosomal dominant retinitis pigmentosa: a novel mutation at the peripherin/RDS locus in the original $6 \mathrm{p}$-linked pedigree. Genomics 1992;14:805-7.

43. Kikawa E, Nakazawa M, Chida Y, Shiono T, Tamai M. A novel mutation (Asn244Lys) in the peripherin/RDS/ gene causing autosomal dominant retinitis pigmentosa associated with bull's eye maculopathy detected by non-radioisotopic SSCP. Genomics 1994;20:137-9.

44. McLaughlin ME, Sandberg MA, Berson EL, Dryja TP. Recessive mutations in the gene encoding the betasubunit of rod phosphodiesterase in patients with retinitis pigmentosa. Nature Genet 1993;4:130-4.

45. Seabra MC, Brown MS, Goldstein JL. Retinal degeneration in choroideremia: deficiency of $\mathrm{Rab}$ geranylgeranyl transferase. Science 1993;259:377-81.

46. Van den Hurk JAJM, Van Zandvoort PM, Brunsmann F, Pawlowitzki IH, Holzgreve W, Szabo P, et al. Prenatal exclusion of choroideremia. Am J Med Genet 1992;44:822-3.

47. Redmond RM, Graham CA, Kelly ED, Coleman M, Nevin NC. Prenatal exclusion of Norrie's disease. Br J Ophthalmol 1992;76:491-3.

48. Furu T, Kaariainen H, Sankila EM, Norio R. Attitudes towards prenatal diagnosis and selective abortion among patients with retinitis pigmentosa or choroideremia as well as among their relatives. Clin Genet 1993;43:160-5.

49. Wertz DC, Janes SR, Rosenfield JM, Erbe RW. Attitudes towards the prenatal diagnosis of cystic fibrosis: factors in decision making among affected families. Am J Hum Genet 1992;50:1077-85.

50. Godfrey $M$, Vandemark N, Wang $M$, Velinov $M$, Wargowski D, Tsipouras $\mathrm{P}$, et al. Prenatal diagnosis and a donor splice site mutation in fibrillin in a family with Marfan syndrome. Am J Hum Genet 1993;53: 472-80.

51. De Paiva S, Ramalho AS. Prenatal diagnosis of sicklecell anemia: perceptions of professionals and patients. Rev Bras Genet 1993;16:1049-56. 